\title{
The Experiences of Students in English Language Teaching on Learning "German as a Foreign Language"
}

\author{
Arzu Orhan ${ }^{1}$ \\ ${ }^{1}$ Department of German Language Teaching, Faculty of Education, Bursa Uludag University, Turkey \\ Correspondence: Arzu Orhan, Department of German Language Teacher Education, Faculty of Education, Bursa \\ Uludag University, Bursa, Turkey. E-mail: mollaoglu@uludag.edu.tr
}

Received: May 28, 2019

doi:10.5539/jel.v8n4p112
Accepted: June 24, 2019 Online Published: July 12, 2019

URL: https://doi.org/10.5539/jel.v8n4p112

\begin{abstract}
The aim of this study is to illustrate the experiences of students who have taken the optional course "German as a Foreign Language" using the textbook "studio d Al" (Funk et al., 2010) at the Department for English Language Teaching at Bursa Uludağ University, and also their reasons for learning a second foreign language. To identify the thoughts and opinions of the students using the textbook, a questionnaire containing ten questions was used. In addition, four questions regarding demographic information were posed to 32 students at the department. The purpose of the study was to analyze the suitability of maintaining the set textbook for the optional course "German as a Foreign Language". The results indicate that, in this optional course, there is a need to use textbooks that are designed according to the combination German after English or German with English. The students have also been given the opportunity to express their opinions concerning whether the hours offered in the curriculum of Bursa Uludağ University were sufficient for them to learn a language at a level that would facilitate their learning of yet another foreign language. The analysis of these data shows that students wished to increase the weekly quota of hours of this course.
\end{abstract}

Keywords: English Language Teaching, German as a second foreign language, textbook evaluation, studio d A1

\section{Introduction}

The learning of any foreign language opens up new dimensions and experiences for students, as well as broadening horizons (Neuner, 2003, p. 22). In the process they gain experience of learning methods and strategies that play an important part in the acquisition of another language. Knowledge of a first foreign language can be used for an efficient learning of another language, thus promoting a process of lifelong learning (Neuner, 2003, p. 23). When beginning their studies of a third language, the students will already have some pre-knowledge of cognitive factors such as awareness, of one's own type of learning and of emotional factors, such as motivation and learning-speech anxiety (Hufeisen, 2001). Most research into the field shows that students with previous experience of language learning know how to approach a language and its vocabulary. Whether the languages to be learned are very similar or different, it is important to activate the learning potential of the students when they are learning the second foreign language. Previous experiences enable students to begin learning another language at a higher level than that of absolute beginners. However, it should not be forgotten that less time is made available for courses in a second foreign language than in the first. Despite this, expectations remain the same; students should attain the same level with their second foreign language. These courses are usually studied at a higher pace and with learning material that is more condensed. This means less time for exercises and hardly time for repetition.

The concept of "learning the German language according to the English language" has had a big impact on Turkish foreign language didactics, something which has been widely recognized and documented in research literature (Hufeisen, 1994; Apeltauer, 1997; Neuner, 1999; Akpınar Dellal \& Bora Günak, 2009; Tönshoff, 2015). According to Ak1llilar (2013, p. 283), situations in which German is taught as a second foreign language after the first foreign language can have both positive and negative effects. It is important to identify the positive effects, to affirm them and to facilitate or promote the learning of more than one language. Thus, learning German with English as a base can be advantageous, due to the linguistic similarities between the two languages, factors that can serve to simplify the learning process. Studies have shown the links between English and German and that they have similarities in grammar and vocabulary, which makes it easier for Turkish learners of 
these languages to understand the structure of a second foreign language (Apeltauer, 1997, p. 91). Relatively recent research has underscored the benefices of using English as a means of learning German. Referring to similar-sounding words can function as a "learning bridge" (Güler, 2000, p. 4), which allows lecturers to proceed more rapidly and efficiently. Lectures can be developed through time-saving and efficient teaching with learning procedures that involve both language systems. They can also serve to develop vocabulary knowledge relatively quickly, without time-consuming work, as well as raising topics of discussion.

Several research studies have sought to underscore that learning German can be facilitated for students participating in English Language Teaching, too (Neuner, 1999, p. 15; Rohs, 2001; Hufeisen, 1994). Neuner's (1996, p. 212) study revealed that students in English Language Teaching (henceforth ELT) are often directed through a world of English, in order to connect with German. In a later article, Neuner (1999, p. 15) refers to the significance of pre-stored language elements and experiences from learning processes with previous languages. Similarly, Hufeisen (1994, p. 6) mentions that learning German by way of English triggers a so-called "Aha experience", since using appropriate elements from English, will spark an existing language potential.

English has taken the lead as the first foreign language in Turkey, Europe and many other countries around the world. It has been highlighted that, in the Turkish school system, German has consistently followed as the leading second foreign language after English according to previous studies (Tapan, $2000 \mathrm{a} / \mathrm{b}$; Polat \& Tapan, 2002). This situation has remained unchanged in Turkey. There is a need for the development of textbooks for teaching German as a foreign language (henceforth referred to as DaF), i.e., German after English, and for the design and implementation of this sequential method according to the guidelines for tertiary language teaching that are required (Güler, 2000; Polat, 1998). At present, we are seeing more and more of the German after English combination. In view of the fact that there is generally less time allotted to the teaching of a teaching a second foreign language than for the first, according to Neuner (2003, p. 26), the learning material would need to be gone through more quickly. He therefore recommends that one should aim for an economization of the learning process through a meaningful use of existing knowledge from the acquisition of English when studying German.

As noted by Richards (2012), the choice of textbook is a crucial factor, as are the lecturers, which have a major role in teaching and learning processes. He points out that good teaching material allows lecturers and students to have a clear overview of the course content and of the linguistic means and objectives of foreign language teaching. The course material constitue the basis of the curriculum, help to introduce greater standardization in the course, provide a variety of methods, create a rich linguistic acquisition environment, help students to plan activities in the course, and support visualization. However, one of the studies, conducted by Gilmore (2007, p. 112), revealed that creative and authentic activities do facilitate language learning, but finding appropriate materials in Foreign Language Teaching is often seen as time-consuming and difficult to combine with lectures. The beginner's level is seen as especially problematic (Guariento \& Morley, 2001, p. 348). There is a wide range of teaching materials that lecturers can use in Foreign Language Teaching. It is important, as other studies also show (Kartal, 2018, p. 673), to choose materials that are interesting and up-to-date, since students do not want to work with long and boring texts or materials in class.

This research endeavor hopes to add educational culture-specific insights into current research and trigger further inquiry in foreign language teacher education. The study focusses on the situation of students in ELT at Bursa Uludağ University (henceforth BUU) who are learning German as a second foreign language. An important fact to consider is that the students come from varying types of high schools. Students from private schools have have generally had a more intense encounter with the foreign language than students from state schools. In the optional course "DaF", lecturers agreed to use the textbook "studio $d$ Al". This study aims to show how students perceive the use of this textbook. The current study will provide an insight into the degree to which this textbook has proved to be suitable for the "DaF" course at BUU.

The research questions addressed in the study are: a. Is "studio $d$ Al" a suitable textbook for the optional course "DaF" from the point of view of students' previous experiences? b. Why do students want to learn German in ELT at BUU? c. What effect does previous experience of foreign language learning have on the ELT students when learning their second foreign language?

\section{Research Goal}

The study aims to present the opinions and thoughts of the students in ELT as to how the textbook might support them in the optional course "DaF" when learning German, and whether this course with its two hours a week has been optimally placed in the curriculum at BUU. By means of a survey, the language learning experience is presented with reference to the textbook used by ELT students. Furthermore, the students are given the 
opportunity to justify their choice of language, in this case German. The ultimate purpose of this study is the development of ideas that could make this course more effective and useful.

\section{Methodology}

The textbook "studio $d$ Al" was used in the optional course "DaF" in the academic year 2016-2017. In this questionnaire, which was used in article was adapted from the previous study by Solak, Eken and Bayar (Solak, Eken, \& Bayar, 2015) the ELT students were asked about their experiences with the textbook. The questionnaire has been used to determine their opinions and thoughts through statements about the textbook in the optional course "DaF". According to Baştürk (2011), various methods of analysis can be used to understand the behavior of people. In this study, the quantitative research method was used, the main goal of which is to provide a descriptive and realistic picture of the research object.

\subsection{Information about the Textbook "Studio d A1"}

The textbook "studio $d A l$ " is intended for adult students without prior knowledge from home or abroad. The teaching material is based on the Common European Framework of Reference (CEFR) (Trim, Brian, \& Daniel, 2001) and on the Can descriptions of "Profile Deutsch", which in three (or five) volumes leads to a certificate in German. The focus is on a course-book which includes an exercise section. It contains twelve units in which topics, grammar, vocabulary and linguistic structures are introduced. The units are followed by sections devoted to deepening and repetition. At the end of each volume there is a test (Modelltest Start Deutsch). The textbook also contains several bilingual glossaries, an audio $\mathrm{CD}$ connected to the textbook, a separate audio $\mathrm{CD}$, various audio texts, dialogues, poems, songs, etc., and exercises related to each unit of the textbook. The book contains a video with movie-like scenes together with lots of geographic information about Germany, a language training booklet and a student CD-ROM. The publisher's website offers authentic material for students to use as a supplement to the textbook in the courses. In terms of content, the textbook "studio $d$ Al" is characterized by considerable diversity. The topics of the textbook are listed in Table 1.

Table 1. Topics in the textbook "studio d A1"

\begin{tabular}{ll}
\hline Lesson 1 & Conversations in the café \\
Lesson 2 & Communication in the course \\
Lesson 3 & Sights in Europe \\
Lesson 4 & Living environments \\
Lesson 5 & Dates and appointments / Punctuality inter-culturally \\
Lesson 6 & Orientation at the workplace \\
Lesson 7 & Professional and everyday life \\
Lesson 8 & An excursion through Berlin / Guidance in the city \\
Lesson 9 & Holiday in Germany \\
Lesson 10 & At a market / In a supermarket / Eating habits \\
Lesson 11 & Fashion when buying clothes / Weather \\
Lesson 12 & Body and Sport / At the doctor / Emotions \\
\hline
\end{tabular}

\subsection{Participants}

The study was conducted with the participation of 32 volunteer ELT students ( 27 women, 5 men) enrolled in the English Teaching Program of the Faculty of Education at BUU in the academic year of 2016-2017. The ELT student group took part in the optional course "DaF" using the textbook "studio d Al".

\subsection{Sample and Data Collection}

At the end of the academic year 2016-2017 a questionnaire was sent to the students through Google Docs. The 32 students who have taken this course activated the link and reached the questionnaire, answering each question and saving their answers. The author reached those answers through her Google account and downloaded them to her computer as an e-table in an Excel format. These data were then analyzed in the SPSS 25 program.

The questionnaire, about which the students had previously been informed, attempts to determine their opinions and thoughts on the textbook in the optional course "DaF". It was also emphasized that the feedback given by the students is important for the improvement and restructuring of the teacher training program. Therefore, they were asked to give their opinions in Turkish.

The aim of the first part of this questionnaire has been to identify demographic data. Here can be found information about gender and age, general information about the language level and interest in other foreign 
languages. This demographic data should provide a closer knowledge of the student group. The second part of the questionnaire contains two questions in which the ELT students are asked to state whether or not the weekly lessons for the optional course have been sufficient. These statements are intended to draw attention to the need for strengthening this course. The third part of the questionnaire asks why ELT students have chosen to learn German. The students had eight different statements to choose from, which they had to tick. The purpose of this question is to determine whether connecting to the English language facilitated the learning of German. The fourth part of the questionnaire consists of 10 statements, which have as their goal to determine the attitudes of the students to the textbook. On the 10 Likert scale, the data in the fourth part is evaluated using SPSS, "strongly agree" with 1 , "agree" with 2 , "neither" with 3 , "disagree" with 4 and "strongly disagree" named with 5 . The results are presented in tables of frequency and percentage values and are also commented on. In its final form, the questionnaire contained 10 questions and 4 questions that included demographic information. The reliability value is illustrated in Table 2. The questionnaire was found reliable with an alpha value of .784.

Table 2. Reliability statistics

\begin{tabular}{ll}
\hline Cronbach's Alpha & N of Items \\
\hline 0.784 & 10 \\
\hline
\end{tabular}

\subsection{Analyzing the Data}

The data was analyzed using SPSS 25.0. The analysis determines the attitude of students to the textbook and their reasons for learning German through the use of frequency and percentage calculations. A One-way ANOVA test was applied, taking into account the language levels of the students in the frequency and percentage calculations.

\section{Findings}

\subsection{The Findings Related to the Demographic Variables}

This section presents demographic information about the student group. It was conducted with the participation of 32 volunteer students enrolled in the English Teaching Program, and the results are shown in Table 3. In numerical terms, the study group consists of $84.4 \%$ women $(\mathrm{n}=27)$ and $15.6 \%$ men $(\mathrm{n}=5)$. The students are aged between 19-37. The average age is 21.97 . The studied group is linguistically heterogeneous i.e., apart from a few participants with some knowledge of German, most participants had no previous knowledge of the language. However, all participants in the course had it in common that they were learning for the first time and using the same textbook.

Table 3. Student group demographics

\begin{tabular}{llll}
\hline & & Frequency $(\mathrm{n}=32)$ & Percent $(\%)$ \\
\hline Gender & Woman & 27 & 84.4 \\
& Man & 5 & 15.6 \\
Age & Average & 21.97 & \\
\hline
\end{tabular}

Table 4 is intended to provide more information on the previous experience and knowledge in German that ELT students have. As can be seen below, $71.9 \%$ (23) of the participants assessed themselves as being at A1 (Beginner) level, followed by the value at 25\% (8) at A2 (Elementary) level. Only 3.1\% (1) participant rated his level as B1 (Intermediate).

Table 4. What level of German do you have?

\begin{tabular}{lll}
\hline Level & Frequency $(\mathrm{n}=32)$ & Percent $(\%)$ \\
\hline A1 & 23 & 71.9 \\
A2 & 8 & 25.0 \\
B1 & 1 & 3.1 \\
\hline
\end{tabular}

The model of the language sequence "English as the first foreign language and German as the second foreign language" is widespread in Turkey in the school language offering. ELT students at BUU are given the 
opportunity to choose between German or French. Interest in other foreign languages always has an important role for learners to become able to empathize with people from other cultures, to prepare to enter a skilled workforce for the professional world, or just to boost self-confidence. The ELT students have their reasons for learning German. In relation to this, they were asked to state which other foreign languages they would have liked to learn in optional courses. The following Table 5 shows the actual wishes. The findings show that other languages, especially Spanish, with a value of $47.6 \%$ (15), are considered to be far more interesting than German. This is followed by the Russian language with 30.4\% (10). Chinese and Japanese also find a place in the table, but with a lower value.

Table 5. Which other foreign languages would you learn in the optional course?

\begin{tabular}{lll}
\hline Language & Frequency $(\mathrm{n}=32)$ & Percent $(\%)$ \\
\hline Spanish & 15 & 47.6 \\
Russian & 10 & 30.4 \\
French & 3 & 9.5 \\
Japanese & 3 & 9.5 \\
Chinese & 1 & 3.1 \\
\hline
\end{tabular}

\subsection{The Findings Related to the Situation at the English Teachers Department}

Before presenting the results, there are factors that need to be clarified beforehand. The optional course is included in the university program for students in their third academic year. Turkish students' study a second foreign language at the Foreign Languages Department, in their 5th, 6th and 7th semesters. At BUU, the ELT students have two choices, German or French. The majority choose German, which they already had some knowledge of. This is due to the fact that in Turkey, German is taught as a second or further foreign language in primary or high school. This makes it easier for students to learn German more quickly than French because it is in its structural form closer to English. These courses, offered as two 45-minute sessions a week, build upon a basic level of German already acquired among students. However, from a teacher's point of view, the limited number of hours is far from satisfactory, if they are to reach a more advanced level of German. In order to provide a more accurate picture of the situation, and the position of the optional course in the curriculum, the ELT students were asked in the questionnaire whether two hours a week for the optional course "DaF" is sufficient or if the optional course "DaF" should be increased by 2 hours a week.

Table 6 shows that $65.6 \%$ (21) of students do not find 2 hours a week enough for the optional course "DaF".

Table 6. For the optional course "German as a foreign language" 2 hours a week is sufficient

\begin{tabular}{lll}
\hline & Frequency $(\mathrm{n}=32)$ & Percent $(\%)$ \\
\hline Yes & 11 & 34.4 \\
No & 21 & 65.6 \\
\hline
\end{tabular}

As Table 7 illustrates, the majority of students $71.9 \%$ (23) find that the number of hours a week of the optional course should be increased.

Table 7. The optional course "German as a foreign language" with 2 hours a week should be strengthened

\begin{tabular}{lll}
\hline & Frequency $(\mathrm{n}=32)$ & Percent $(\%)$ \\
\hline Yes & 23 & 71.9 \\
No & 9 & 28.1 \\
\hline
\end{tabular}

The answers to the question "why" they were learning the foreign language were given in Table 8 . It was confirmed that the ELT students, who had previously learned German 12.5\% (4), preferred English as a second foreign language $21.9 \%$ (7) because of the similarity to German $21.9 \%$ (7) and chose German because it's is in the university curriculum $21.9 \%$ (7). At the same time, it became clear to the students that German offers opportunities for their future $12.5 \%$ (4), as, like English, it is an international language 6.3\% (2) they were interested in $6.3 \%$ (2). As you can see, Table 8 represents the importance of choosing the optional German course "DaF". 
Table 8. Results of the data in frequency and percentage calculations

\begin{tabular}{lll}
\hline Why are you learning German? & Frequency $(\mathrm{n}=32)$ & Percent (\%) \\
\hline Because it is in the curriculum of the university. & 7 & 21.9 \\
Because I want to learn a second foreign language. & 7 & 21.9 \\
Because it has a similarity to English. & 5 & 15.6 \\
Because I want to develop my knowledge of German. & 4 & 12.5 \\
Because it offers a good opportunity for my future. & 4 & 12.5 \\
Because German is a worldwide and internationally important language. & 2 & 6.3 \\
Because I have an affection for German. & 2 & 6.3 \\
Because I am interested in German literature. & 1 & 3.1 \\
\hline
\end{tabular}

\subsection{The Findings Related to the Textbook "Studio d A1"}

In Table 9, the students have commented on various statements about "studio $d$ Al". While the majority, 68.8\%, (22) were positive about statement D1, there were also students who were uncertain $21.9 \%$ (7) or did not agree $9.4 \%$ (3). As a result, more than half describe the textbook in this course as appropriate. The next statement D2 shows that most of the ELT students are fairly positive $71.9 \%$ (23), while some students seem insecure $21.9 \%$ (7) and positive $6.3 \%$ (2). It can be said that the majority of students describe the content of the textbook as going from simple to complex, from concrete to abstract, from known to unknown. It can be seen in statement D3, that most of the students $54.2 \%$ (18) felt that the quality of the listening exercises was not up to standard and inadequate. Only a small number of answers were positive $12.5 \%$ (4), while some expressed incertitude $31.3 \%$ (10). When we look at the answers in the D4 statements, a majority considered this weakness as negative $46.9 \%$ (15), and almost the same number are not sure $43.8 \%$ (14). Very few students were positive $9.4 \%$ (3\%). The answers might be an indication that the textbook would be more suitable for activities in the classroom. Furthermore, students lack the time to fulfill the demand for learning outside the course. Looking at the next statement, D5, a large number of students $78.1 \%$ (25) felt negative, while the other students were more positive $21.6 \%$ (7). The results yield that the students mentioned that they often had to decide for themselves how to approach the individual exercises since there were no indications of social forms for various exercises. In statement D6 it can be seen that more than half 59.4\% (19) of ELT students were of the opinion that the textbook does not increase the interest in the courses. We can also see that there are ELT students who are not sure 31.3\% (10). Only a few agree $9.4 \%$ (3) with this statement. In the next statement D7 we can see that about half of the students $43.8 \%$ (14) find that the activities encourage communication. The other half are not sure $28.1 \%$ (9) or disagree $25 \%$ (8) with this statement. If we look at the answers to statement D8, the majority $68.7 \%$ (22) believe that the textbook offers enough thematic diversity. This result shows that the ELT students understand the topics in this textbook as motivating, ranging from concrete things in private living spaces (conversations in the café, living environments) and from professional life (working life) to abstract topics such as fashion and emotions. Only a few $15.6 \%$ (5) are not sure and some $12.5 \%$ (4) disagree. In the next statement D9 we can see that more than half of the students $59.4 \%$ (19) found the exercises with placement exercises, supplementary exercises, and questions formulated in the textbook rather conventional and traditional. Some ELT students $15.6 \%$ (5) considered it regrettable that the exercise apparatus was not more creative and not adapted to their target group. On the basis of the answer to statement D10, it can be said that for the ELT students, who attend the optional course "DaF", there is a need to select textbooks and teaching materials that also include the language learning experience and knowledge of English to achieve an effective course. Only 25\% (8) want to learn German again with this textbook. The other ELT students have a negative attitude.

Table 9a. Results of the statements of the students about the textbook "studio d Al" (continued)

\begin{tabular}{|c|c|c|c|c|c|c|c|c|c|c|}
\hline & \multicolumn{2}{|c|}{ D1* } & \multicolumn{2}{|c|}{$\mathrm{D} 2 *$} & \multicolumn{2}{|c|}{ D3* } & \multicolumn{2}{|l|}{ D4* } & \multicolumn{2}{|c|}{ D5* } \\
\hline & $\mathrm{F}^{*}$ & $\mathrm{P}^{*}$ & $\mathrm{~F}^{*}$ & $\mathrm{P}^{*}$ & $\mathrm{~F}^{*}$ & P* & $\mathrm{F}^{*}$ & $\mathrm{P}^{*}$ & $\mathrm{~F}^{*}$ & $\mathrm{P}^{*}$ \\
\hline Strongly agree & 8 & 25 & 4 & 12.5 & 1 & 3.1 & 0 & 0 & 0 & 0 \\
\hline Agree & 14 & 43.8 & 19 & 59.4 & 17 & 53.1 & 3 & 9.4 & 2 & 6.3 \\
\hline Neither & 7 & 21.9 & 7 & 21.9 & 10 & 31.3 & 14 & 43.8 & 5 & 15.6 \\
\hline Disagree & 3 & 9.4 & 2 & 6.3 & 4 & 12.5 & 9 & 28.1 & 21 & 65.6 \\
\hline Strongly disagree & 0 & 0 & 0 & 0 & 0 & 0 & 6 & 18.8 & 4 & 12.5 \\
\hline
\end{tabular}


Table 9b. Results of the statements of the students about the textbook "studio d A1"

\begin{tabular}{|c|c|c|c|c|c|c|c|c|c|c|}
\hline & \multicolumn{2}{|c|}{ D6* } & \multicolumn{2}{|c|}{$\mathrm{D} 7 *$} & \multicolumn{2}{|c|}{ D8* } & \multicolumn{2}{|c|}{ D9* } & \multicolumn{2}{|c|}{ D10* } \\
\hline & $\mathrm{F}^{*}$ & $\mathrm{P}^{*}$ & $\mathrm{~F}^{*}$ & $\mathrm{P}^{*}$ & $\mathrm{~F}^{*}$ & $\mathrm{P} *$ & $\mathrm{~F}^{*}$ & $\mathrm{P}^{*}$ & $\mathrm{~F}^{*}$ & $\mathrm{P}^{*}$ \\
\hline Strongly agree & 0 & 0 & 0 & 0 & 1 & 3.1 & 0 & 0 & 1 & 3.1 \\
\hline Neither & 10 & 31.3 & 9 & 28.1 & 5 & 15.6 & 6 & 18.8 & 13 & 40.6 \\
\hline Disagree & 17 & 53.1 & 8 & 25 & 4 & 12.5 & 14 & 43.8 & 8 & 25 \\
\hline
\end{tabular}

Note. *F: Frequency, *P: Percent

*D1: I think that the textbook and its activities are appropriate.

*D2: I think that the content of the textbook corresponds to the principles of the course, from simple to complex, from concrete to abstract, from known to unknown.

*D3: I think that the quality of the listening texts in the textbook is not sufficient and understandable.

*D4: I think the textbook encourages learning outside the classroom.

*D5: I think that the activities in the textbook lead to individual and group work.

*D6: I believe that the textbook increases interest in the courses.

*D7: I think that the activities in the textbook sufficiently stimulate communication.

*D8: I believe that the textbook offers enough thematic diversity.

*D9: The textbook gives the opportunity to approach activities creatively, authentically, and independently.

*D10: In the coming years, I think it is appropriate to re-select the same textbook.

The results of the One-way ANOVA test were given in Table 10. This test was conducted taking into account the language levels of the students to illustrate whether or not there are any differences between the statements made by the students regarding the textbook. It can be seen that the difference between the variances in the levels of students between the statements of the students about the textbook is not significant. This means that the ratio between the variances does not deviate significantly. This means that all the students who are at levels A1, A2 and B1 have evaluated the statements in the same way. 
Table 10. One-way ANOVA test results to indicate whether there is a significant difference in the textbook evaluations of students according to their language level

\begin{tabular}{|c|c|c|c|c|c|c|c|c|c|c|}
\hline & & \multicolumn{3}{|c|}{ Descriptive Statistics } & \multicolumn{6}{|c|}{ ANOVA Test } \\
\hline & & $\mathrm{N}$ & Mean & SD* & & SS* & $\mathrm{df}$ & MS* & $\mathrm{F}$ & Sig. \\
\hline \multirow[t]{4}{*}{ D1* } & A1 & 23 & 2.17 & 0.887 & $\mathrm{BG}^{*}$ & 0.914 & 2 & 0.457 & 0.524 & 0.598 \\
\hline & $\mathrm{A} 2$ & 8 & 2.00 & 1.069 & $\mathrm{WG}^{*}$ & 25.304 & 29 & 0.873 & & \\
\hline & B1 & 1 & 3.00 & & Total & 26.219 & 31 & & & \\
\hline & Total & 32 & 2.16 & 0.920 & & & & & & \\
\hline \multirow[t]{4}{*}{$\mathrm{D} 2 *$} & A1 & 23 & 2.65 & 0.832 & $\mathrm{BG}^{*}$ & 1.251 & 2 & 0.626 & 1.085 & 0.351 \\
\hline & A2 & 8 & 2.25 & 0.463 & $\mathrm{WG}^{*}$ & 16.717 & 29 & 0.576 & & \\
\hline & B1 & 1 & 2.00 & & Total & 17.969 & 31 & & & \\
\hline & Total & 32 & 2.53 & 0.761 & & & & & & \\
\hline \multirow[t]{4}{*}{ D3* } & A1 & 23 & 2.17 & 0.717 & $\mathrm{BG}^{*}$ & 0.289 & 2 & 0.145 & 0.244 & 0.785 \\
\hline & $\mathrm{A} 2$ & 8 & 2.38 & 0.916 & $\mathrm{WG}^{*}$ & 17.179 & 29 & 0.592 & & \\
\hline & B1 & 1 & 2.00 & & Total & 17.469 & 31 & & & \\
\hline & Total & 32 & 2.22 & 0.751 & & & & & & \\
\hline \multirow[t]{4}{*}{ D4* } & A1 & 23 & 3.74 & 0.964 & $\mathrm{BG}^{*}$ & 3.440 & 2 & 1.720 & 2.223 & 0.126 \\
\hline & $\mathrm{A} 2$ & 8 & 3.00 & 0.535 & $\mathrm{WG}^{*}$ & 22.435 & 29 & 0.774 & & \\
\hline & B1 & 1 & 4.00 & & Total & 25.875 & 31 & & & \\
\hline & Total & 32 & 3.56 & 0.914 & & & & & & \\
\hline \multirow[t]{4}{*}{ D5* } & A1 & 23 & 3.78 & 0.850 & $\mathrm{BG}^{*}$ & 0.306 & 2 & 0.153 & 0.279 & 0.759 \\
\hline & $\mathrm{A} 2$ & 8 & 4.00 & 0.000 & $\mathrm{WG}^{*}$ & 15.913 & 29 & 0.549 & & \\
\hline & B1 & 1 & 4.00 & & Total & 16.219 & 31 & & & \\
\hline & Total & 32 & 3.84 & 0.723 & & & & & & \\
\hline \multirow[t]{4}{*}{ D6* } & A1 & 23 & 3.57 & 0.788 & $\mathrm{BG}^{*}$ & 0.223 & 2 & 0.111 & 0.183 & 0.834 \\
\hline & $\mathrm{A} 2$ & 8 & 3.50 & 0.756 & $\mathrm{WG}^{*}$ & 17.652 & 29 & 0.609 & & \\
\hline & B1 & 1 & 4.00 & & Total & 17.875 & 31 & & & \\
\hline & Total & 32 & 3.56 & 0.759 & & & & & & \\
\hline \multirow[t]{4}{*}{$\mathrm{D} 7 *$} & $\mathrm{~A} 1$ & 23 & 2.87 & 0.968 & $\mathrm{BG}^{*}$ & 0.016 & 2 & 0.008 & 0.009 & 0.991 \\
\hline & A2 & 8 & 2.88 & 0.835 & $\mathrm{WG}^{*}$ & 25.484 & 29 & 0.879 & & \\
\hline & B1 & 1 & 3.00 & & Total & 25.500 & 31 & & & \\
\hline & Total & 32 & 2.88 & 0.907 & & & & & & \\
\hline \multirow[t]{4}{*}{ D8* } & $\mathrm{A} 1$ & 23 & 2.48 & 0.947 & BG* & 0.016 & 2 & 1.365 & 1.864 & 0.173 \\
\hline & A2 & 8 & 2.25 & 0.463 & $\mathrm{WG}^{*}$ & 25.484 & 29 & 0.732 & & \\
\hline & B1 & 1 & 4.00 & & Total & 25.500 & 31 & & & \\
\hline & Total & 32 & 2.47 & 0.879 & & & & & & \\
\hline \multirow[t]{4}{*}{ D9* } & $\mathrm{A} 1$ & 23 & 3.61 & 1.033 & BG* & 2.730 & 2 & 1.808 & 1.849 & 0.627 \\
\hline & A2 & 8 & 3.13 & 0.835 & $\mathrm{WG}^{*}$ & 21.239 & 29 & 0.978 & & \\
\hline & B1 & 1 & 5.00 & & Total & 23.969 & 31 & & & \\
\hline & Total & 32 & 3.53 & 1.016 & & & & & & \\
\hline \multirow[t]{4}{*}{ D10* } & $\mathrm{A} 1$ & 23 & 3.09 & 0.949 & $\mathrm{BG}^{*}$ & 0.893 & 2 & 0.446 & .474 & \\
\hline & A2 & 8 & 3.25 & 1.035 & WG* & 27.326 & 29 & 0.942 & & \\
\hline & B1 & 1 & 4.00 & & Total & 28.219 & 31 & & & \\
\hline & Total & 32 & 3.16 & 0.954 & & & & & & \\
\hline
\end{tabular}

Note. *SD: Standard Deviation, *SS: Sum of Squares, *MS: Mean Square, *BG: Between Groups, *WG: Within Groups

*D1: I think that the textbook and its activities are appropriate.

*D2: I think that the content of the textbook corresponds to the principles of the course, from simple to complex, from concrete to abstract, from known to unknown.

*D3: I think that the quality of the listening texts in the textbook is not sufficient and understandable.

*D4: I think the textbook encourages learning outside the classroom.

*D5: I think that the activities in the textbook lead to individual and group work.

*D6: I believe that the textbook increases interest in the courses.

*D7: I think that the activities in the textbook sufficiently stimulate communication.

*D8: I believe that the textbook offers enough thematic diversity.

*D9: The textbook gives the opportunity to approach activities creatively, authentically, and independently.

*D10: In the coming years, I think it is appropriate to re-select the same textbook.

\section{Discussion and Conclusion}

The overarching goal of this study has been, to present the opinions and thoughts of the ELT students about the textbook "studio A1", which was used in the optional course "DaF" during the academic year 2016-2017.The 
first research question was aimed to ascertain if the textbook was suitable for the optional course. Related to these results, various forms of information have emerged. In the context of the answers in Table 9 to statement D3 "I think that the quality of the listening texts in the textbook is not sufficient and understandable", listening comprehension may be considered as a weak point. Listening comprehension during the German lessons can even be described as one of the main problems. It was particularly noticeable that many students have been critical of the quality of the audio texts in the textbook. In their opinion, most of the audio texts were spoken rapidly. According to Vielau (2000), listening texts should not contain many unfamiliar words. He limits this to seven words in new teaching material. For instance, listening texts should not be used as learning texts that introduce and practice new grammatical features and vocabulary. Therefore, it is recommended for the teachers on the course to focus on training and practicing the necessary vocabulary for the appropriate audio texts. This could be achieved to make it clear to the students that texts from textbooks, or well-spoken audio texts from the media can be difficult to understand, if they have not yet learned enough vocabulary. This will show that vocabulary is the most important key to understanding.

Again, in relation to the first research question, statement D4 reflects the question whether the textbook encourages the students' learning outside the classroom. More than half thought that this textbook did not motivate them to practice the foreign language outside the classroom. In this context, the results suggest that participating in the Erasmus program may be an incentive to increase their motivation to learn another foreign language. It gives the opportunity for them to continue their studies abroad for a certain period of time. It is therefore also expected that the students will adopt a reflective attitude with the help of lectures and will later be ready to integrate culture into their courses (Karatepe \& Y1lmaz, 2018, p. 836). This will give them the opportunity to recognize intercultural similarities and differences, strengthen their self-confidence and ability to overcome problems, the ability to take responsibility, the tendency to use positive thinking, the dismantling of prejudices and the development of an awareness of their own culture and language. Also, it can be said, in terms of professional development, that the Erasmus program leads to positive experiences for students. It has been stated in a study by Demir and Demir (2009, p. 103) that Erasmus programs enable the development of professional self-confidence, recognition of other or different education systems and the development of foreign language levels. This exchange also allows them to decrease their low motivation to learn the other language. Including the culture of the target language country thus gives them the insight that learning languages is important and necessary for them and opens a window to a different way of living. Therefore, this type of motivation can definitely be considered as an influential factor for low motivation (Clark \& Trafford, 1996). The results of the present study reinforce that one of the most important aspects of learning foreign languages is gaining internal and external motivation.

On the subject of the first research question about the views of students using the textbook, the majority answered that the activities in the course book did not guide them towards doing individual or group work. Although the textbook also contains activities based on individual or group work, students mentioned that they often had to decide for themselves how to work with the individual exercises, since there were no suggestions for social interaction in the exercises. Previous researchers have pointed out the importance for students to collaborate in the context of teaching. Three possible work options have been identified: partner, group and plenary work (Drumm, 2007; Grunder, Ruthemann, Scherer, Singer, \& Vettinger, 2007).

More than half of the students found that the textbook does not offer the opportunity to approach activities creatively, authentically, and independently. According to the findings in statement D10 the majority of the students were not completely satisfied about learning with the textbook. Moreover, the data also indicates that students were not completely satisfied with the textbook and it did not raise their interest in pursuing further German language studies. On the whole, findings show that the textbook did not quite fulfill the needs of the students. However, you can change the lessons completely or adjust the material if necessary and present it to the students as logically as possible. The appropriate grammar is generally developed by lecturers, who have a basic knowledge of the system and are endowed with professional qualifications that are relevant, so they can equip the students with the necessary learning strategies and learning techniques (Ceylan, 2005, p. 61). It is, however, also important to remember that there are additional materials available for use in every textbook. In summary, the answer to the first research question suggest that the textbook can be used for the optional course "DaF" considering the experiences of the students, but for a more effective learning procedure, the use of a textbook is required which allows recourse to the English language. These results seem to be in line with those found in previous research due to the fact that students wish to have recourse to their first foreign language, something which confirms the advantages of using textbooks that conform to the principle of combining German with English (Maden Sakarya, 2005; Köksal, 2008, p. 86). 
The second research question aimed to illustrate why students learn German. The ELT students indicated that they find foreign language teaching and learning another foreign language relevant. As pointed out in Table 8, they state a wish to learn another foreign language as a reason for learning German. Other research (Çelikkaya, 2013, p. 107) confirms the recognition that learning German as a second foreign language is important. Furthermore, in Table 6, the students express the view that the teaching hours for an effective learning of another foreign language in courses at universities are not sufficient. Other researchers have also deplored the lack of teaching hours, of practical training and memorizing of grammatical structures, as well as the shortage of lecturers (Bayraktaroğlu, 2012; Alptekin, 2012). As also noted by Kırmızı (2009, p. 273), the hours allotted to German lessons in our educational system are not sufficient. To achieve success, the weekly German lessons should be strengthened. This result also applies to the optional course "DaF" at BUU. As the results in Tables 6 and 7 show, the majority of those who participated in this study also stated that they did not find two hours a week for the optional course "DaF" enough and want to increase the number of hours in order for students to become successful when learning another foreign language.

With regard to the final research question about the effect of previous experience of learning a foreign language, the results of this study show that similarities between languages can have a positive impact on teaching and is therefore desirable. It can be seen in Table 8 that students recognize the similarities between the languages English and German. Also, importantly, they point out this similarity as a reason for their wanting to learning German. As a lecturer, it is therefore important to benefit from this situation and to use teaching methods that connect with the English language. According to Memiş and Erdem (2013, p. 317) suitable teaching methods for the corresponding target language should be developed for the creation of an effective and useful course. It is important to know the target group in order to use appropriate teaching materials or textbooks. Rowntree (1981, pp. 35-36) argues that a foreign language lecturer should choose the appropriate textbook for the course and consider basic activities that require the participation of students. The fact that both languages have a structural similarity, in words and in some grammatical rules, and, most importantly that they are learned one after the other, should be considered as vital for a foreign language lecturer or learner to establish a connection between the two languages. In her study, Maden Sakarya (2005) mentions that activation an existing learning potential can stimulate conscious learning, transfer possibilities and, in a systematic way, help to identify interference hazards. This procedure can be developed into concrete teaching. According to Merkelbach $(2003$, p. 547) it should also draw attention to phonetic, grammatical, pragmatic and lexical contrasts or similarities when another foreign language is to be learned.

Finally, it can be said, that knowledge of the first foreign language serves to increases motivation and help students to venture to learn more language. As noted by Cummins (2008) students with different foreign language skills usually learn faster, because they already have learning strategies and can provide transfer services. For this reason, it is recommended that lecturers of the optional course "DaF" should have knowledge of the first foreign language of the students and be able to analyze the connection between the two languages and integrate similarities and differences during the lessons. It should be emphasized that the teaching of the additional foreign language, should not be a copy of the first course, but it should mean a new learning experience for the students through the use existing transfer potential in a targeted manner (Tönshoff, 2015, p. 98). Therefore, it would be an important result to say, not German to English, but instead of considering German with English and not looking at them separately but in combination.

One should also take into consideration the need for teaching materials aimed for the learning of German specifically as a second foreign language after English. With a textbook that considers these principles, higher motivation and success can be assured. On the one hand, this allows lecturers to offer a faster and more efficient entry into the German language. On the other hand, the lecturers have the opportunity to develop time-saving and efficient teaching and learning procedures that bring both languages with their numerous similarities in the language systems together. All these results point to the need to reflecht upon the selection of suitable textbooks that would enhance both the teaching and the learning process.

\section{References}

Akpınar, D. N., \& Bora, G. D. (2009). İkinci yabancı dil olarak Almanca öğrenen öğrencilerin birinci yabancı dil

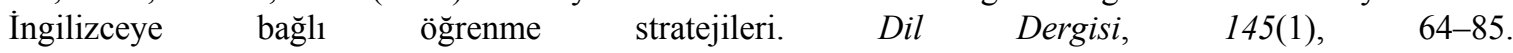
https://doi.org/10.1501/Dilder_0000000116

Alptekin, C. (2012). Yabancı dil eğitiminde öğretmen yetiştiren akademisyenlerin nitelikleri. In A. Sarıçoban \& H. Öz (Eds.), Türkiye'de Yabancı Dil Eğitiminde Eğilim Ne Olmalı? 1. Yabancı Dil Eğitimi Çalıştayı Bildirileri, 12-13 Kasım 2012 (pp. 15-26). Ankara: Hacettepe Üniversitesi 2014 Yayınları. 
Apeltauer, E. (1997). Grundlagen des Erst- und Zweitsprachenerwerbs. Fernstudieneinheit 15. München: Langenscheidt.

Baştürk, S. (2011). Matematik öğretmen adaylarının Eğitim Fakültesindeki eğitim-öğretim sürecini değerlendirmeleri. Uluslararast Insan Bilimleri Dergisi, 8(1), 58-94. Retrieved from http://www.InsanBilimleri.com

Bayraktaroğlu, S. (2012). Neden yabancı dil eğitiminde başarılı olamıyoruz? In A. Sarıçoban \& H. Öz (Eds.), Türkiye'de Yabancı Dil Eğitiminde Eğilim Ne Olmalı? 1. Yabancı Dil Eğitimi Çallştayı Bildirileri, 12-13 Kasım 2012 (pp. 9-14). Ankara: Hacettepe Üniversitesi Yayınları, 2014.

Çelikkaya, Ş. (2013). Ortaöğretim öğrencilerinin ikinci yabancı dil Almanca dersine yönelik tutumları. Middle Eastern \& African Journal of Educational Research, 5, 96-109.

Ceylan, Y. (2005). Grammatik in der Deutschlehrerausbildung: Überlegungen zur Gestaltung der Grammatik-Lehrveranstaltungen in Bezug auf Lernerautonomie beim Erwerb von Grammatikkenntnissen. Uludă̆ Üniversitesi Eğitim Fakültesi Dergisi, 18(1), 47-65. Retrieved from http://dergipark.org.tr/uefad/issue/16681/173334

Clark, A., \& Trafford, J. (1996). Return to Gender: Boys' and Girls' Attitudes and Achievements. Language Learning Journal, 14, 40-49. https://doi.org/10.1080/09571739685200371

Cummins, J. (2008). BICS \& CALP: Empirical and Theoretical Status of the Distinction. In N. Hornberger (Eds.) Literacy. Encyclopedia of Language and Education (2nd ed., pp. 71-83). New York: Springer Science + Business Media LLC. https://doi.org/10.1007/978-0-387-30424-3_36

Demir, A., \& Demir S. (2009). Erasmus programının kültürel arası diyalog ve etkileşim açısından değerlendirilmesi (Öğretmen adaylarıyla nitel bir çalışma). Uluslararası Sosyal Araşstırmalar Dergisi / The Journal of International Social Research, 2(9), 95-106. Retrieved from http://www.sosyalarastirmalar.com/cilt2/sayi9pdf/demir_aysinsemra.pdf

Drumm, J. (Eds.) (2007). Methodische Elemente des Unterrichts. Sozialformen, Aktionsformen, Medien. Göttingen: Vandenhoeck \& Ruprecht.

Funk, H., Demme, S., Kuhn, C., \& Bayerlein, O. (2010). studio d A1. Deutsch als Fremdsprache. Kurs- und Übungsbuch. Berlin: Cornelson.

Gilmore, A. (2007). Authentic materials and authenticity in foreign language learning. Language Teaching, 40(2), 97-118. https://doi.org/10.1017/S0261444807004144

Grunder, H.-U., Ruthemann, U., Scherer, S., Singer, P., \& Vettinger, H. (2007). Unterricht. Verstehen - planengestalten - auswerten. Baltmannsweiler: Schneider Verlag Hohengehren.

Guariento, W., \& Morley, J. (2001). Text and Task Authenticity in the EFL Classroom. ELT Journal, 55(4), 347-353. https://doi.org/10.1093/elt/55.4.347

Güler, G. (2000). Deutsch als zweite Fremdsprache im schulischen Fremdsprachenunterricht in der Türkei: Perspektiven für die Didaktik und Methodik des Deutschen als zweite Fremdsprache in der Deutschlehrerausbildung. Zeitschrift für Interkulturellen Fremdsprachenunterricht (Online), 5(2), 11. Retrieved from http://zif.spz.tu-darmstadt.de/jg-05-2/beitrag/gueler1.html

Hufeisen, B. (1994). Englisch im Unterricht Deutsch als Fremdsprache. München: Klett.

Hufeisen, B. (2001). Kurze Einführung in die linguistische Basis. In G. Neuner \& B. Hufeisen (Eds.), Mehrsprachigkeit und Tertiärsprachenlernen. Tertiärsprachen lehren und lernen. Beispiel Deutsch nach Englisch. Teil 1. Linguistische Grundlagen und didaktisch-methodische Konzeption. Erprobungsfassung (pp. 7-11). München: Goethe Institut Inter Nationes.

Karatepe, C.., \& Yılmaz, D. (2018). Teaching culture in EFL context: Student teachers' perspective. Turkish Studies International Periodical for the languages, Literature and History of Turkish or Turkic, 13(11), 823-839. https://doi.org/10.7827/TurkishStudies.13373

Kartal, E. (2018). Opinions and suggestions of teacher candidates on the teaching of the reading skill in French language: The example of Uludag University. European Journal of Educational Research, 7(3), 667-677. https://doi.org/10.12973/eu-jer.7.3.667

Kırmızı, B. (2009). Etkili bir Almanca Öğretimi için öğretmen beklentileri. Ballkesir Üniversitesi Sosyal Bilimler Enstitüsü Dergisi, 12(22), 268-280. $\quad$ Retrieved from 
http://sbe.balikesir.edu.tr/dergi/edergi/c12s22/makale/c12s22m19.pdf

Köksal, H. (2008). Deutsch als zweite Fremdsprache nach Englisch. Zum Einfluss der ersten Fremdsprache zur zweiten Fremdsprache. Hasan Ali Yücel Eğitim Fakültesi Dergisi, 2(1), 69-88. Retrieved from https://dergipark.org.tr/download/article-file/93100

Maden, S. S. (2005). Anforderungen an ein Lehrwerk für Deutsch als Tertiärsprache in der Türkei. Zeitschrift für Interkulturellen Fremdsprachenunterricht (Online), 10(2), 10. Retrieved from https://tujournals.ulb.tu-darmstadt.de/index.php/zif/article/download/433/409

Memiş, M. R., \& Erdem, M. D. (2013). Yabancı dil öğretimde kullanılan yöntemler, kullanım özellikleri ve eleştiriler. Turkish Studies-International Periodical for the Languages, Literature and History of Turkish or Turkic, 8(9), 297-318. https://doi.org/10.7827/TurkishStudies.5089

Merkelbach, C. (2003). Deutsch nach Englisch in Taiwan. Der nicht positife Einfluß des Erwerbs des Englischen als L2 auf den Erwerb des Deutschen als L3. info DaF, 30(6), 541-548. http://doi.org/10.1515/infodaf-2003-0603

Neuner, G. (1996). Deutsch als zweite Fremdsprache nach Englisch - Überlegungen zur Didaktik und Methodik und zur Lehrmaterialentwicklung für die Drittsprache Deutsch. Deutsch als Fremdsprache, 33(4), 211-217.

Neuner, G. (1999). Deutsch nach Englisch. Übungen und Aufgaben für den Anfangsunterricht. Fremdsprache Deutsch, 20(1), 15-21.

Neuner, G. (2003). Lehrwerke. In K. R. Bausch, H. Christ \& H. J. Krumm (Eds.), Handbuch Fremdsprachenunterricht (pp. 399-402). Tübingen u.a.: A. Francke Verlag.

Polat, T. (1998). Chancen und Probleme des Deutschen als Fremdsprache in der Türkei unter dem Aspekt der Mehrsprachigkeit. Alman Dili ve Edebiyat Dergisi, 10, 129-144. Istanbul: Edebiyat Fakültesi Basımevi. Retrieved from http://dergipark.gov.tr/iuaded/issue/1042/11776

Polat, T., \& Tapan, N. (2002). Präsentation eines laufenden Forschungsprojekts: Einstellungen türkischer Studierender zum Angebot und Lehren und Lernen von Fremdsprachen. In P. Wiesinger \& H. Derkits (Eds.), Akten des X. Internationalen Germanistenkongresses Wien 2000.

Richards, J. C. (2012). The role of textbooks in a language program. Retrieved from https://www.professorjackrichards.com/wp-content/uploads/role-of-textbooks.pdf

Rowntree, D. (1981). Developing Courses for Students. London: British Standards Institution.

Solak, E., Eken, H., \& Bayar, A. (2015). Yabancı dil ders kitabı değerlendirme ölçeği geçerlik ve güvenirlik çalışması. International Journal of Social Sience, 38(2), 121-133. https://doi.org/10.9761/JASSS3036

Tapan, N. (2000a). Zur Entwicklung der Sprachenvielfalt und der interkulturellen Kompetenz im schulischen Fremdsprachenunterricht in der Türkei. In M. Durzak \& B. Laudenberg (Eds.), Literatur im interkulturellen Dialog (pp. 552-568). Bern. Berlin u. a: Peter Lang AG, Europäischer Verlag der Wissenschaften.

Tapan, N. (2000b). Fremdsprachenunterricht im Primarbereich der Türkei. Vortrag auf dem 18. Kongress für Fremdsprachendidaktik Dortmund 1999. In E. Apeltauer (Ed.), Erziehung zur Zwei- und Mehrsprachigkeit. Flensburger Papiere zur Mehrsprachigkeit und Kulturenvielfalt im Unterricht. Heft 24/25. (pp. 40-60). Flensburg: Universität Flensburg.

Tönshoff, W. (2015). Deutsch als zweite oder weitere Fremdsprache - vom Lernerprofil zu einer spezifischen Didaktik und Methodik. In S. Hoffmann \& A. Stork (Eds.), Lernerorientierte Fremdsprachenforschung und -didaktik (pp. 97-110). Tübingen: Narr Verlag.

Trim, J., Brian, N., \& Daniel C. (2001). Gemeinsamer europäischer Referenzrahmen für Sprachen: lernen, lehren, beurteilen. Berlin: Langenscheidt.

Vielau, A. (2000). Methodik des Kommunikativen Fremdsprachenunterrichts. Berlin: Cornelsen.

\section{Copyrights}

Copyright for this article is retained by the author, with first publication rights granted to the journal.

This is an open-access article distributed under the terms and conditions of the Creative Commons Attribution license (http://creativecommons.org/licenses/by/4.0/). 